\title{
Creation of a female Archetype in Bayen
}

\author{
Arunabha Bose \\ Vivekananda College, University of Delhi. Email: boseashisnd@gmail.com
}

\begin{abstract}
Mahasweta Devi's fiction explores gender as a category that is not insulated from political formations. Discursive practices of colonial exploitation, superstition, primitivism and Neocolonial operations structure and reconstitute the category of gender. Mahasweta chronicles the lives of aboriginal communities in India's tribal belt to whom the privileged entitlements of constitutional equality and citizenship are not extended. In the historical formation of the postcolonial nation state these aboriginal communities are lumped together as ethnographic minorities and are excluded from privileged endowments of postcolonial modernity. In Bayen there is an irreducible difference between the narrative of history of the postcolonial nation state which seeks to reverse untouchability through social engineering and the mythological narrative which consumes the woman, Chandi and transforms her into a grotesque spectre. Bayen tries to recuperate the lost subjectivity of the female subaltern subject by recovering the identity and personalised history of the woman, Chandi behind the fearsome spectre of the witch, bayen.
\end{abstract}

Keywords: aboriginal, mythology, spectre, Untouchability, Subaltern

In Bayen, Mahasweta shows Chandi embodying the female archetype. Her name carries forward her identification with the destructive and forbidding aspect of female energy. As a terrifying spectral presence relegated to the womb like darkness of the forest and feared as hostile, vengeful and emasculating, she almost becomes a corporeal figuration of the id, the archetypal female principle. In the contested space of shifting power relations, such a castrating female agency has to be contained and thus she is ostracised for being a witch. Her alienation gives her a limited power as her gaze can be mortifying but this is accomplished only at the cost of her demonization and desubjectivisation. Ironically in the end, her martyrdom deifies her; Mahasweta Devi parodies hegemonic nationalist narratives which reappropriated the figure of woman for divinisation of the motherland. The irony here is that the deified woman lacks the "purity" of the Hindu woman in the nationalist iconography as caste contaminates and pollutes the female subaltern subject.

Just as Mary Oraon's hybrid and thus "contaminated" subject position in the short story, Hunt makes her the ostracised "Other" in the decolonised nation state which is in the ideological grips of a Neo-colonial state machinery and altered labour relations; Chandi in Bayen becomes a spectral presence with whom there can be no communication. Thematically one can see how the alienation of Chandi mimics the political estrangement of the ethnographic minorities or aboriginals in both pre-colonial and post-colonial India. For the metropolitan elite, the aboriginals or the adivasis constitute a spectre to be feared and derided; to be segregated from the "uncontaminated" space of the post-colonial metropolis. There can be no communication, no

(c) AesthetixMS 2016. This Open Access article is published under a Creative Commons Attribution Non-Commercial 4.0 International License (http://creativecommons.org/licenses/by-nc/4.o/), which permits non-commercial re-use, distribution, and reproduction in any medium, provided the original work is properly cited. For citation use the DOI. For commercial re-use, please contact aesthetixms@gmail.com. 
identification between the post-colonial (Metropolitan, Hindu) subject and the aboriginal (subject without an identity). In Chandi's social alienation from the community of Doms, Mahasweta turns the metaphor of political estrangement literal by making Chandi the ostracised and simultaneously feared "Other" of an already politically Othered community.

Chandi's tragedy can be seen as precipitated by the ritualised embeddedness and cultural sway of mythology. There are multiple registers of mythology in the world that Mahasweta Devi unravels. There is first, the personalised mythology of Chandi; Chandidasi evokes the legacy of being the daughter of the renowned Kalu Dom who gave shelter to the exiled King Harishchandra. This narrative functions as an originary narrative which locates the Dom community's traditional profession at a precise moment. It's rootedness in the scriptural tradition of India is still used to explain away the peculiarity of the Dom community's untouchable labour thus proving its persisting cultural currency. Mahasweta takes us into the heart of a lesser known India where mythology predominates over the political narrative of history. One might ask that if the colonial archives of pre-modern India as well as the postcolonial historiography of the Indian nation state in the making have both conspicuously occluded and erased the historical and genealogical traces of the hundreds of ethnic minorities; can't these mythological tales be seen as the only legitimate versions of tribal origins? Mahasweta Devi shows that India's "tribal belt" is still an anachronistic terrain, where two different worlds - the archaic, ahistorical, primeval and primitive world of occult practices and the historical, developing world of postcolonial modernity collide. While Chandi remains imprisoned in the former, her husband Malinder and son Bhagirath are shown to be drifting ideologically towards the latter. There is in fact a dissonance between the two worlds so that Bhagirath who is born in the politically decolonised nation state has forgotten about his biological mother who has been swallowed by mythology and transformed into a local legend. The early signs of the intrusion of modernisation are signalled by Malinder's employment at a subdivisional morgue, where rather than cremating the dead at the burning ghats he was socially extolled to the more "respectable" ranks of a government servant bleaching the skeleton of unclaimed dead bodies. No doubt this social mobilisation is effected by constitutional and legislative policies of social engineering but Malinder's untouchability remains irreversible, so that his son Bhagirath although freed from inheriting the traditional ancestral profession is only admitted in a school where the academic space is spliced along caste lines. Mahasweta's textual irony lays bare the absurdity of such social engineering and recalibration projects in an India where mythology substitutes history, occultism replaces modernity and legends and folklore replace historical archives. Bhagirath's lived experience counteracts and delegitimises the social viability of his cherished public school lessons which have taught him that "after the Untouchability Act of 1955, there were no longer any untouchables in India".

The second kind of myth is the one culturally scripted by the whole Dom community circling around the figure of the Bayen or witch. This socially enforced myth obviates Chandi the daughter, the wife, the mother and the guardian of graves and makes her captive to a socially generated fiction. While Chandi's self-generated mythology of belonging to the lineage of Kalu Dom who established his dominion over all the burning ghats of the world counteracts the social script of stigmatisation, the communal mythology of the Bayen strips Chandi of precisely this social power which accrued from her paternal inheritance. "A bayen is not an ordinary witch; she cannot be killed like an ordinary witch because to kill a bayen means the death of your children". Mahasweta's narrative deliberately draws attention to its textual and constructed nature. She trades the homogeneity of a polished and unruptured narrative in favour of a fragmented and dissonant text where the culturally generated narrative of mythopoesis in italicised form interrupts the formal cadence of Chandi's personal narrative. This lack of homogeneous 
integration in the rhetorical structure signals the impossibility of creating a homogeneous postcolonial nation state where the differentiated and diversified cultural histories of ethnographic minorities cannot be subsumed within the unifying narrative of an all-encompassing Indian state. Mahasweta denounces the textual authority of authorship as she is neither a colonial ethnographer nor a postcolonial historiographer, who both claim to authentically "know" and thus represent the subaltern subject. Mahasweta's narrative adopts a double narrative focalisation; on the one hand it chronicles with journalistic objectivity the processes of historical modernisation with the construction of a railway line along Sonadonga, Palasi and Dhubulia (Places invisible in the political geography of an urbanised metropolitan nation state). On the other hand, it reads like a quasi mythological tale of an ethnographic community fashioned as an alternative tale of origin in which they claim to derive their existence from the Goddess Ganga. The river Ganga washes away ritualised pollution, sins and provides salvation. In an ironic reappropriation of this myth, the Doms, although themselves impure and polluted, purify the society by cremating dead bodies which would otherwise rot and contaminate. The Doms call themselves Gangaputras and Gangaputris. In fact, Chadidasi and Malinder's son is named after an ancient king who brought Ganga from heaven to purify and cleanse the earth.

Gender occupies a central position in Mahasweta's pro adivasi fiction and her activist writing published in the Bengali periodical Bortika which are predominantly about political reorganisation and restructuring of the postcolonial space to accommodate the subaltern subject. The female subaltern subject one might say is outside of institutionalised history and popular discourse; she remains a spectral presence, an apparition who evokes fear in the popular imagination of the educated elite. Chandi, the witch similarly is exiled not just from the social space of the aboriginal community but also from historical archives of the modern nation state as she remains captive to a life denying culturally reinforced mythology. In any patriarchal society, the woman is the "Other", the carrier of difference. In a contesting paradigm of dissymmetrical power relations, Man structurally occupies the dominant subject position of normality; thus woman becomes the monstrous gendered "Other". In the social transformation of Chandi into a witch, Mahasweta makes this "monstrosity" of the female subject a concretely embodied material reality. If one deconstructs the process of discursive formation of the female subject, one realises that the female body in itself stands for an anatomical monstrosity. In opposition to the male body which remains stable, the female body is deformed by virtue of lacking the phallus and unstable by virtue of its menstruating, child bearing and lactating nature, what Kristeva calls the "Abject body".

Mahasweta offers a kind of social polarisation between two alternative subject positions occupied by Chandi/Bayen and two alternative conceptions of the female body. On the one hand we have Chandi the woman as a concretely embodied presence, as a Lived Body who experiences the world phenomenologically and a historically produced subject who supports her family by carrying forward her father's trade. This woman is a dutiful and loving wife who indirectly supports her husband's bourgeois aspirations, an indulgent mother and a guardian of unprotected graves of children. On the other hand we have the Bayen, a grotesque disfigured apparition who embodies the distorted image of the woman in the social imagination. By transforming Chandi into a witch, the Dom community dislocates her from her identity giving subject positions, that of a daughter, wife and mother. This dislocation is almost a desubjectivisation as she becomes an enigmatic fixture of society who is dualistically positioned as the "other" so that society can define itself as the standard bearing norm. She is stripped of all identifiable markers of womanhood or domesticated femininity as she becomes a terrible and terrifying emasculating spectre. Unlike the care giver Chandi, the bayen's shadow is conceived to be death dealing if it falls on a child and her 
gaze is deemed fatal; she is a crafty sorceress who devours children and whose sexual perversion borders on necrophilia as she is believed to suckle and rear dead children.

Similarly, there are two polarised configurations of the female body. In one, the female body as experienced by the embodied subject is seen as self-pleasuring and embodying healthy feminine sexuality; Chandi gained the adoration of local admirers because of her sexual desirability, in fact the suppleness of her tender flesh is reminisced by Malinder in one poignant moment in the story. The territory of Chandi's body is emptied of these positive significations and reterritorialized by the phallocentric signifying economy which brands her as a hypersexualised object. The agents of this phallocentric discourse do not allow Chandi to appropriate her body, through their commodifying gaze they misappropriate the breasts overflowing with milk as a sign of Chandi's deviation from the regulatory structures of "acceptable" sexuality. Thus, from being an embodied self-pleasuring subject, she gets embedded in a superstitious patriarchal narrative. The Corporeal materiality of Chandi's body is replaced by the bayen's distorted, grotesque, foul smelling, disease ridden and defeminised body. The bayen's emaciated body becomes the object of persecution and chastisement rather than erotic adoration.

The central problematic of the story is the reason behind Chandi's ostracisation and demonization, which is never explicitly spelled out. I would like to locate Chandi's banishment to the margins of the Dom community in her refusal to subscribe to the conventional index of culturally sanctioned femininity. Chandi after her father's death voluntarily chooses to carry out his ancestral trade, an ostensibly male vocation. "I am Chandi. The daughter of the Gangaputta. My father is dead. Give me his rations instead". Gayatri Spivak has underlined the impossibility of subaltern self-representation in postcolonial regimes, but here the female subaltern subject does speak. And it is through her utterance that she reconfigures her subject position, she is not a selfeffacing virgin rendered desolate by the loss of patriarchal protection but a woman who actively yields political agency by adopting her father's vocation. She proves to be equal to the challenge offered by her profession, "The word fear was foreign to Chandi", she actively visualises fighting fire eating jackals to protect the graves of infants. She reconfigures and recontextualises her subject position by proudly asserting her lineage. Rather than exhibiting the proscribed markers of shame and timidity she is boastful and proud. Thus, not only does she reject the pejorative and reductive definition of Self scripted by the Dom community which reduces the concretely embodied female subject to monolithic coordinates of caste and gender but fashions an alternative self-definition and sustains it rigorously. It is precisely this non-conformist position of Chandi, the ambivalence of her gendered subject position and the dissolution of a fixed identity to embody a fluid, almost "gender free" identity in which she acts like a man that triggers hostility. Ironically Chandi's posthumous deification does not restore her essential subjectivity but reconstitutes her "alienation" from her lived body just as her demonization did.

\section{References}

Devi, Mahasweta. (Winter2001/Spring2002). Bayen. India International Centre Quarterly Vol 28, No 4, pp. $355-368$ 